Esteve, M; Di Lorenzo, F; Inglés, E; Puig, N; (2011) Empirical Evidence of Stakeholder Management in Sports Clubs: The Impact of the Board of Directors. European Sport Management Quarterly, 11 (4) 423 - 440. 10.1080/16184742.2011.599210. Downloaded from UCL Discovery:

http://discovery.ucl.ac.uk/1462902.

\title{
ARTICLE
}

\section{Empirical Evidence of Stakeholder Management in Sports Clubs: The Impact of the Board of Directors}

\author{
Marc Esteve ${ }^{1}$, Francesco Di Lorenzo ${ }^{1}$, Eduard Inglés ${ }^{2}$, Núria Puig ${ }^{2}$ \\ ${ }^{1}$ ESADE Business School, Ramon Llull University \\ ${ }^{2}$ GISEAFE (Grup d'Investigació Social i Educativa de l'Activitat Física i l'Esport), Institut \\ Nacional d'Educació Física de Catalunya, Barcelona
}

\begin{abstract}
A major challenge for non-profit sports organizations is how to raise resources from their stakeholders. The present article empirically assesses how the management of stakeholders can affect the resources raised by non-profit sports organizations. The moderating effect of particular characteristics of the board of directors is also considered. Evidence is obtained by surveying a large sample of sports clubs from Catalonia, Spain. Results indicate how the quality of relations between sports clubs and their external stakeholders relate positively to the financial and non-financial contributions of stakeholders. A club's financial resources are also positively linked to the amount of time its board of directors is willing to invest. Our results represent a major contribution to the management of sports clubs, demonstrating that sports organizations should prioritize the management of their external stakeholders.
\end{abstract}

\section{Acknowledgments}

Research for this article was carried out as part of a project of the Observatori Català de l'Esport financed by the Secretaria General de l'Esport de la Generalitat de Catalunya. The authors are grateful for helpful comments from the Editors, and from two anonymous reviewers.

\section{Introduction}

Sports management scholars are increasingly interested in the impact of stakeholders on the management of sports organizations (Leopkey \& Parent, 2009). Prior research has used the descriptive perspective of stakeholder theory to identify the stakeholders of sports organizations (Parent, 2008; Parent \& Deephouse, 2007). Recent work has gone further by considering how stakeholders might influence strategic activities such as risk management (Leopkey \& Parent, 2009). However, research on the role and impact of stakeholders in sports organizations is still developing and needs further study.

Our research empirically measures the impact of stakeholder relations on the resources that a non-profit sports organization is able to attract. We look at characteristics of the Board of Directors, and how these may affect the resources a sports club can raise from external stakeholders. In particular, we focus on the relation between the management of stakeholders and financial and non-financial contributions to the club.

In order to test out hypothesis, we conducted a survey on a sample of 1000 sports clubs in Catalonia, Spain. Results indicate that the financial and non-financial contributions of the stakeholders are positively related with the quality of relations that they have with the sports 
clubs. In addition, in the case of the club's financial resources we also find positively correlations with the amount of time that its board of directors invests in the management of the club.

The remainder of this paper is organized as follows. We begin by presenting a review of the literature on stakeholder theory. We then analyze the major features of sports clubs and present our hypotheses. We describe the methodology used in this study, and present empirical results. In the fifth section, we relate our findings to the existing literature; we conclude by developing guidelines to be considered in further studies.

\section{Theory and Hypotheses}

A Review of Stakeholder Theory

Stakeholders are groups or individuals "who can affect or [are] affected by the achievement of the firm's objectives" (Freeman, 1984, p. 25). Yet, as popular and richly descriptive as this term may seem, there is still no agreement on what Freeman (1994) calls "The Principle of Who or What Really Counts" (Mitchell, Agle, \& Wood, 1997). Since Freeman (1984) introduced stakeholder theory into the management lexicon, a diverse stakeholder literature has developed. Literature reviews broadly classify this work into three traditions: descriptive, normative and instrumental (Donaldson \& Preston, 1995).

Descriptive theory is used to explain specific corporate characteristics and behaviors, including the nature of the firm, the way managers think about managing, how board members think about the interests of corporate constituencies, and how some corporations are actually managed (see, for example, Mitchell, Agle, \& Wood, 1997). Normative theory is used to interpret the function of the corporation, including the identification of moral or philosophical guidelines for the operation and management of corporations. As an example of the normative application of the stakeholder theory, Agle, Mitchell, and Sonnenfeld (1999) assessed the impact of stakeholder characteristics on the social-corporate and financial performance of organizations, finding only statistical support for the first concept. Donaldson and Preston (1995) proposed that the normative realm, which concerns the way managers deal with corporate stakeholders, is the most important area of stakeholder theory. Not surprisingly, there has been considerable discussion in both academic and practitioner circles about which normative principles firms should use to shape their relations with stakeholders (Berman, et al., 1999). Finally, instrumental theory, in conjunction with available descriptive and empirical data, is used to identify the connections, or lack of connections, between stakeholder management and the achievement of traditional corporate objectives (for example, profitability and growth). Whatever their methodologies, these studies have tended to generate "implications", suggesting that adherence to stakeholder principles and practices can achieve conventional corporate performance objectives as well or better than rival approaches. Table 1 summarizes the principal management considerations of these three different perspectives:

\section{Insert Table 1 About Here}

Studies employing an instrumental perspective on stakeholder theory have attempted to verify whether firms that are responsive to stakeholders are more successful (Jones, 1995; Wood, 1991). In particular, a growing empirical literature has investigated whether excess profits accrue to firms that are socially responsible or environmentally conscious (Margolis \& Walsh, 2001; Waddock \& Graves, 1997). Following this stream of research, Berman et al. (1999) developed testable models around the two competing perspectives: normative versus instrumental. Their first model, which they call strategic stakeholder management, reflects an instrumental approach and suggests that concern for stakeholders is motivated by a desire to improve financial performance. Their second model, which they refer to as intrinsic stakeholder commitment, rests on the assumption that firms have a normative or moral commitment to advance stakeholder interests, and that this commitment shapes firm 
strategy and influences financial performance. Using a longitudinal test, Berman and his colleagues find support for only the instrumental approach (Harrison \& Freeman, 1999). Therefore, stakeholder relations both link and affect the relationship between a firm's strategy and its financial performance.

The objective of this paper is not merely to describe and classify the stakeholder map of sports clubs, in accordance with the descriptive approach. Nor does it pretend to explain why a club's Board of Directors should engage with its stakeholders, in accordance with normative theory. Instead, the present article embraces the instrumental approach and seeks to determine how the management of external stakeholders influences their contributions to the organization. We also consider how the particular characteristics of a Board of Directors affect the interaction between these two constructs.

\section{Stakeholder Theory in Sports Clubs}

Sports clubs, as non-profit organizations, have some important features that must be taken into consideration in this study (see, for a recent review, Thiela \& Jochen, 2009). Their chief characteristics are that: they are oriented towards the fulfillment of the interests of their members; membership is voluntary; they are independent of third parties and sustained by membership quotas and, in the majority of cases, the work they undertake is voluntary (Heinemann, 1999). However, the concept of the sports club is an umbrella-term that describes a great variety of bodies, from huge, professional organizations to small, local sports associations.

In Catalonia, as in the rest of Spain, one must take into consideration the influence of more than 40 years of the Franquist regime, in which the right to associate was highly restrained, causing a deterioration of civil society and its capacity to initiate. When democracy was restored, it was generally believed that the voluntary sports sector was unable to provide access to sport for the general population (Puig, Martínez, \& García, 2010). This was such an accepted argument that, in 1978, the Spanish constitution made access to sport an explicit responsibility of the State. The public sector, and particularly the Councils, acquired a major role in sports development from that moment.

Since $87 \%$ of the Catalan sports clubs were founded after the reestablishment of democracy (Secretaria General de l'Esport, 2010, 23); they emerged within a society that had given the public sector responsibility for the provision of sports services for the population. Thus, sports clubs in Spain developed alongside a public sector that was creating a space for itself in social and public life and, more importantly, needed to legitimize its existence. At the same time, sports clubs needed to position themselves with respect to the public bodies being simultaneously developed. It was not just a matter of funding, but of defining the aspects of public life served by each organization (Puig, Martínez, \& García, 2010).

Because these clubs have created tight ties of dependency with other sports organizations, we cannot say that they are completely independent of third parties. Membership dues account for just $48.8 \%$ of their average annual income (Secretaria General de l'Esport, 2010, 36). Therefore, attracting financial resources to develop their activities by cultivating relationships with their stakeholders is the key to success. Their supporters fall into two main categories: public organizations and sports federations-not including the big professional sport clubs, such as the football clubs (Heinemann, 1999).

Two types of contribution are made by stakeholders:

1) Financial Resources: As non-profit organizations, sports clubs are eligible for financial assistance from public organizations. The welfare state is considered responsible for sport and the practice of physical activities (Heinemann, 2005; Heinemann \& Puig, 1996). Public organizations therefore support the development of sports clubs as a strategy to bring sport closer to society. 
2) Non-financial Resources: The contributions made by other organizations to sports clubs are not limited to funds. Sports clubs often receive in-kind support, including facilities, sports equipment and technical expertise. For example, the Council of a specific municipality may not fund the local basketball sports club directly, but may instead allow players to train and develop their activities at the municipal basketball court.

The expenses of a sports club generally exceed the financial resources provided by its members. Sports organizations must therefore raise funds or acquire assets useful for the development of their activities. However, there are several possible approaches, some bureaucratic and others informal. Whatever the case, sports clubs often apply for support from the same organizations, since the concentration of sports clubs is high in countries like Spain (see García-Ferrando, 2006). For this reason, the relationship between clubs and their potential sponsors is linked to the contributions they can hope to receive. Thus, our first hypotheses are:

H1a: Those sports clubs that have good relations with their stakeholders will benefit from high receipt of financial resources.

H1b: Those sports clubs that have good relations with their stakeholders will benefit from high receipt of non-financial contributions.

The Board of Directors as a Moderator

The characteristics of the Board of Directors are related to the development of an organization's strategy (Hambrick, 2007; Hambrick \& Mason, 1984). In the case of a sports organization, the composition and managerial strategy of the Board of Directors has been a recurrent topic during the last decade (see, among others, Ferkins, Shilbury, \& McDonald, 2005; Heinemann, 1999; Hoye \& Cuskelly, 2003). Inglis (1997) found that the Board of Directors played a major role in managing the internal and the external actors in an organization. Ferkins (2009) analyzed the role of the Board of Directors in enhancing an organization's strategy. Among her findings, the author discovered that Boards that participated more fully in the management of their sports organizations performed more capably as managers. In the same vein, it has recently been confirmed that levels of knowledge amongst board members of voluntary sports organizations have an important impact on the decision-making process (Soares, Correia, \& Rosado, 2010). Thus, the Board of Directors has a key role in the advancement of a sports organization. The Board can impact and play an active role in the implementation of an organization's strategy.

Sherry and Shilbury (2009) found evidence of the effect that specific board characteristics have on the performance of sports organizations. When assessing the characteristics of the Chief Executive Officers of major Australian sports organizations, the authors found that the levels of education of the Board of Directors were related to the performance of the organization. In general, boards consisting of relatively highly-educated people manage sports organizations more effectively. As a result, we offer the following hypotheses:

H2a: The higher the level of dedication of a sports club's Board of Directors, the more financial resources the club will receive from its stakeholders.

H2b: The higher the level of dedication of a sports club's Board of Directors, the more nonfinancial resources the club will receive from its stakeholders.

H3a: The higher the level of education of a sports club's Board of Directors, the more financial resources the club will receive from its stakeholders.

H3b: The higher the level of education of a sports club's Board of Directors, the more nonfinancial resources the club will receive from its stakeholders. 
Heinemann (1999) has an explanation for this correlation between a sports club's Board of Directors and resources. The author argues that, when sports clubs select a range of very different professionals for their boards, each member brings a subset of relations with managers of other organizations that can benefit the sports club. In practice, this means that if a sports club needs to negotiate a strategic issue with another organization, it is highly probable that a member of its Board of Directors will have a contact in that organization who can facilitate the negotiations.

In the same vein, Chelladurai (1987) claims that a successful way to accumulate resources in sports clubs is to have "powerful boards". The author argues that clubs must create boards of professionals who are able to bring their experience, expertise, and their contacts with other organizations to the club. These characteristics of the Board of Directors can improve the club's relationship with its stakeholders, thus increasing resources. Thus, we hypothesize:

H4a. The Board of Directors, through the dedication and educational levels of its members, will facilitate the transition from good relations with stakeholders to an increase in financial resources.

H4b. The Board of Directors, through the dedication and educational levels of its members, will facilitate the transition from good relations with stakeholders to an increase in nonfinancial resources.

The next section describes the research methodology that has been used to test the hypotheses in this paper.

\section{Data and Methodology}

The data for this paper have been drawn from a large survey administered to the sports clubs of Catalonia in Spain (Secretaria General de l'Esport, 2010). Following previous work by Heinemann and Schubert (1994), a questionnaire was designed for use in face-to-face interviews. Data collection took place between November 2008 and September 2009 and was developed in four steps. First, a letter was sent to all sports clubs from the Catalan public body responsible for sport, the Secretaria General de l'Esport, announcing that they had been selected for the study and encouraging them to participate. Second, the research team contacted each sports club to present the research and ask for its participation. A third contact was made in advance of the interview, asking for specific information about issues including the club's budget, number of employees and number of members. This was done to ensure that respondents would be prepared to provide this information during their interviews. Finally, the researchers developed face-to-face interviews in which interviewees were asked to respond to 52 questions about different characteristics of the sports club. The interviews took 50 minutes on average.

\section{Sample}

The universe of this study consisted of 8285 sports clubs from Catalonia. In order to ensure that results were representative, the study sample was calculated using three criteria: a) Geographical distribution across the four provinces of Catalonia; b) club size and structural complexity; and, c) the number of sports modalities offered by the club. Using these criteria, a sample of 1000 clubs was randomly chosen. Our result will therefore be applicable to $95 \%$ of Catalan sports clubs, with a percentage of error of $\pm 3,00 \%$. The fact that our questionnaire was delivered face-to-face helped to achieve an unusually high response rate (97\%). The data for this study have been gathered from 978 face-to-face interviews.

Variables

Dependent Variables. Given the instrumental approach to stakeholder management that is the basis for this study, the collected resources of sports organizations are the main 
phenomenon of interest. In particular, we aim to explain how variations in the amount of resources collected by Catalan non-profit sports organizations depends on the relationships between stakeholders and boards of directors. The term "collected resources" refers to the total resources that an organization obtains during a specific time period. In this case, we examine two dimensions. First, we distinguish resources as financial and non-financial. Second, we look at the source of these collected resources. Given the non-profit nature of our organizations, most of the resources (especially those that are financial) come from grants donated by public Catalan entities at different levels of public administration. In particular, given the focus of our study on stakeholders relating to Catalan Public Administration, we consider contributions to sports clubs from the Municipality Council, Sports Federations and Regional Sports Council.

Therefore, our two dependent variables are Collected Financial Resources (henceforth CFR) and Collected Non-Financial Resources (henceforth CNFR). The first is formalized as:

$$
\text { C.F.R. } ._{i}=\sum_{j=1}^{3} \text { Sources }_{j}
$$

Where $i$ is the sports organization and $j$ is the type of source, index 1 represents the Municipality Council, 2 the Sports Federations and 3 the Regional Sports Council. CFR is therefore the sum of the monetary resources each sports organization receives.

CNFR can include any type of non-financial asset and sports facility. We have classified such resources into five categories, and we estimate how many non-financial contributions each sports organization collects from different sources. This is formalized as:

$$
\text { C.N.F.R. } ._{i}=\sum_{j=1}^{3}\left(\sum_{t=1}^{5} \text { Sources }_{t}\right)_{j}
$$

Where $i$ is the sports organization, and $j$ is the type of source, index 1 represents the Municipality Council, 2 the Sports Federations and 3 the Regional Sports Council; $t$ represents the category of non-financial resources, indexed from 1 to 5 . CNFR is therefore the sum of the number of types of non-financial resources that each sports organization receives from each different source.

Independent variables. Our independent variables are the quality of relationships between the club and its stakeholders and Board of Directors. In examining the relationship with stakeholders, we focus on the club's relationship with the Municipality Council, Sports Federations and the Regional Sports Council. The first dichotomous question asks respondents whether they have a relationship with each of these organizations. They are next asked to assess the quality of their relations with each organization on a five-point scale ranging from "very bad" to "very good." Therefore, our first independent variable is called Relationships and is calculated as the average of the assessment value for each of three different stakeholders.

In examining the composition of the Board of Directors, we build a construct using two dimensions. First, each board includes four different profiles: the President, Vice-President, Secretary and Treasurer. In most sports organizations, the relationship with public bodies is not the responsibility of a single director; instead, this responsibility is shared among the board members. Second, each board member has characteristics that reflect his or her personal and professional background and organizational commitment. Following previous studies (Sherry and Shilbury, 2009) we chose education and dedication as the two qualities most likely to influence the relationship with stakeholders and collected resources. The former is assessed between 1 and 6, and the latter between 1 and 5 . Therefore, the second independent variable is twofold: Board Education, the average educational level of the four members of the board, and Board Dedication, the average level of dedication (measured as 
time spent promoting the interests of the sports organization) shown by the four members of the board.

Control variables. In order to take into account alternative explanations of variations in collected resources, we introduce control variables into the model. Size is a proxy for the assets and resources (Amis \& Slack, 1996); therefore, we create Size as the log of members of the sports organization. In the same vein, we consider the size of the municipality as a proxy of the resources available to Public Administration. Organizations located in municipalities with more resources have more resources to apply for. Given the local nature of the relationship between non-profit organizations and the Public Administration, resources are very likely to be distributed locally (Krueathep, Riccucci, \& Suwanmala, 2010). To proxy local resources we therefore create Municipality Size as the log of the citizens of the municipality.

The quality of its application for financial and non-financial resources could be important in explaining an organization's success. During and after each application, organizations could learn how to be more successful in obtaining resources, thus increasing their chances of securing resources from the Public Administration in future. Therefore, we create three dummy variables for each type of resource, which takes value 1 if the organization has asked for resources in the past and 0 otherwise. Summing up the three dummy variables we generate Experience.

Organizations with access to good athletes have a higher chance of securing resources from the Public Administration because of the intrinsic need for competitive purpose (maintaining a high standard of athletic performance) and merit. Therefore, we allow for the presence in the organization of athletes who belong to their sport's national team. The variable is Athletic Quality, which equals 1 when there is at least one athlete on any national team and 0 otherwise.

Finally, we allow for internal organizational efficiency, as expressed in the turnover of athletes. Lower levels of turnover reflect stability in the organizations; it is therefore advisable to have better-structured organizations that can develop long-term programs to help athletes develop and improve, thus attracting potential collected resources. We therefore create Member Turnover as the difference between new entrants and departing members.

\section{Models}

In this study, we have two dependent variables. The first is the collected financial resources, which is a continuous variable in nature. Therefore, we specify our estimation model as an Ordinary Least Squared (OLS).

$$
Y_{i}=X_{i} \beta+C_{i}+\varepsilon_{i}
$$

Where $\mathrm{Yi}$ is the amount of collected financial resources by organization $\mathrm{i}, \mathrm{Xi}$ is the vector of independent variables (Relationship, Board Dedication and Board Education), $\mathrm{Ci}$ is the vector of control variables affecting Yit and $\varepsilon i$ is the error term.

The second variable is the amount of non-financial resource that each organization collects. Exploring the descriptive statistics of the CNFR-dependent variable, we notice that the data is strongly skewed to the right; therefore OLS regression would be inappropriate (see Figure 1). Count data often follow a Poisson distribution, so some type of Poisson analysis might be appropriate. Statistical theory states that in a Poisson distribution the mean and variance are the same. 
The variance of CNFR is nearly three times larger than the mean (mean=3.3; variance $=9.0$ ). The distribution of CNFR suggests issues of over dispersion, that is, a greater variance than might be expected in a Poisson distribution. Therefore, to estimate the model for CNFR, Negative Binomial Regression (NBR) can be more appropriate in cases of over dispersion. For both the OLS and NBR models, we control for the robustness of the estimators. For the analysis we use the statistical software STATA SE 10.0.

\section{Results}

Table 2 displays the main descriptive statistics and correlation matrix with related $p$-value for the significance test. In addition, Table 3 shows the results of the models used to test our hypotheses. Models 1-4 relate to the OLS regressions for Collected Financial Resources, and models 5-8 to the Negative Binomial regressions for Collected Non-Financial Resources. Models 1 and 5 contain only control variables, while models 2 and 6 report the main effects of our independent variables. Models 4 and 8 report results on the interaction between Board Education and Board Dedication. For the interpretation of results, we use models 3 and 4 for CFR and models 7 and 8 for CNFR. The results are thus interpreted according to the two dependent variables: financial and non-financial resources.

\section{Insert Table 2 About Here}

As Table 3 shows, our results indicate a positive and significant relationship (at $p<0.10)$ linking good relations between a sports club and its stakeholders and the financial resources those stakeholders can bring to the club. This means that clubs that have good relations with their external stakeholders will benefit from increased financial contributions. Thus, the first hypothesis of this paper is supported $(\mathrm{H} 1 \mathrm{a})$.

When assessing the effect of dedication amongst board members the results are also as expected. With a level of significance of $p<0.01$, there is a strong correlation between the dedication of board members and the financial resources they can obtain from stakeholders. This lends support to our hypothesis $(\mathrm{H} 2 \mathrm{a})$ about the importance of managing the club's stakeholders. According to these results, clubs with more dedicated boards of directors will benefit from increased financial contributions. However, we predicted that the dedication of the board would not be the only factor in this increase. Our third hypothesis ( $\mathrm{H} 3 \mathrm{a}$ ) looks at the relationship between the directors' levels of education and their ability to attract financial resources. As Table 3 illustrates, this hypothesis is not supported. Thus, there is no relation between the levels of education of the Board of and their capacity to raise funding for the organization.

\section{Insert Table 3 About Here}

We predicted that the characteristics of the Board of Directors, in particular their levels of dedication and education, would mediate between good stakeholder relations and the ability to attract financial resources. Thus, boards of directors with more dedication and education would manage stakeholders more effectively when seeking financial resources. However, this interaction effect was not statistically significant. Thus the fourth hypothesis of the paper is not supported $(\mathrm{H} 4 \mathrm{a})$.

A strong and significant correlation is apparent between non-financial resources and a club's good relationship with its stakeholders $(p<0.01)$. This supports hypothesis $\mathrm{H} 1 \mathrm{~b}$. However, there is no correlation between non-financial resources and the dedication of the Board of Directors (H2b). Nor is the Board's educational level significantly related to the acquisition of non-financial resources ( $\mathrm{H} 3 \mathrm{~b}$ ). In assessing the interaction effect between education and dedication in sports clubs' boards of directors, model 8 shows no relationship between the two constructs, giving no support to our last hypothesis (H4b). 
The control variables in the full models reveal some interesting considerations. Club size is a significant predictor of financial resources. As expected, the bigger the sports club, the more financial resources it can collect. Club size is also positively related to the non-financial resources that a club can collect, although the results are not statistically significant. Interestingly enough, the experience level of the Board of Directors does have an impact on the financial resources of the club. This lends some support to the theory that writing funding applications requires a set of skills and capabilities, and involves a learning effect. The participation of athletes in national teams has not been found to correlate with the acquisition of financial resources. The size of a municipality has a significantly negative effect; the bigger the municipality, the less financial support is available for individual clubs. Finally, member turnover, meaning the ratio between new and departing members, is negatively related to financial resources. High levels of turnover are correlated with receiving less funding from stakeholders, although there is no significant correlation for non-financial resource models. The question of athlete quality is worthy of consideration since financial and non-financial results differ. At a significant level of $p<0.10$, those clubs with high-quality athletes do receive higher levels of non-financial support.

\section{Discussion}

Overall, the main results of this paper are fourfold: 1) Sports clubs that have good relations with their external stakeholders will receive more financial and non-financial support from them; 2) the dedication of the board members translates into higher financial contributions from the clubs' external stakeholders; 3) the overall academic attainments of the Board of Directors do not correlate with contributions to the club from external stakeholders; and 4) the characteristics of the Board of Directors do not mediate between good stakeholder relations and contributions from stakeholders. Thus, the present paper has presented important empirical evidence on the role of stakeholder management in acquiring resources for sports clubs. We have also provided a valuable insight into the impact of the Board of Directors on resource collection, and how the Board moderates the stakeholder management effect in this strategic activity. Chelladurai (1987) emphasizes the importance of a "powerful board" in raising resources from other organizations for non-profit sports organizations. The present study corroborates this finding by presenting empirical evidence of the link between good stakeholder relations and the acquisition of financial and nonfinancial resources. In line with other recent research on the impact of board of director characteristics (Soares, Correia, \& Rosado, 2010) it is worth noting that our results showed a strong correlation between board characteristics and resources raised.

It is interesting to see that the educational level of board members was not significantly correlated to the financial and non-financial resources of the club. The results of the present study show that the key factor is the dedication of the Board, not its overall educational level. This adds an interesting perspective to earlier studies that have found the educational level of members of the Board of Directors to be a valid predictor of their ability as sports club managers (Sherry \& Shilbury, 2009). These results, however, derive from a vein of sports organization literature that focuses on the differences between managing a sports club and managing a private enterprise (Heinemann \& Puig, 1996; Horch, 1996).

Arguably, managing a large enterprise or sports club such as the Barcelona Football Club is quite different from managing the majority of clubs in our sample, which are typical of Catalonian sports clubs in being fairly small. $54.3 \%$ of Catalonian clubs have no more 100 members, and 30\% have 100-300 members; this means that the $84 \%$ of Catalan sports clubs are small (having one or a maximum of two sections) and are developed through the voluntary efforts of their members (Secretaria General de l'Esport, 2010). As a consequence, these clubs differ to a great extent from large organizations, regardless of whether they are profit-making or not, both in terms of resources and objectives (Thiela \& Jochen, 2009). 
These clubs are set up to satisfy the interest of a group of people in practicing sports. Members use their clubs to communicate their excitement about participating in competitions, to train and spend time with friends, and to share a common interest. There is no managerial agenda or ambition, such as exists in the economically-driven major clubs (Thiela \& Jochen, 2009). What does exist is a great passion for developing sport. This commitment translates into long hours and strenuous efforts spent cultivating the financial and non-financial contributions needed to develop the activities of the club.

There is no macrostructure-only a small club whose head office may be borrowed from the Council or housed in a member's home. In this sort of sports club, hierarchy is not determined by professional competence (Thiela \& Jochen, 2009) and the resources needed include such benefits as a regular time slot in the municipal sports center or a small subvention to pay for team trips. Necessary resources are acquired through negotiated arrangements with municipality and neighborhood organizers; this builds a network of relational ties with stakeholders able to support and promote the club (Parent, 2008). In Catalonia, these are the Councils and the sports federations. Sports clubs are not businesses, but a social activity that unites civil society.

With regard to the relation between stakeholders and resources, our results do not show any interaction effect with characteristics of the Board of Directors. This may be explained by the concept of the Board's relational resources (Heinemann, 1999). Arguably, those members of the Board with better links to public organizations will be responsible for negotiating with those organizations for resources. This study has controlled for the overall characteristics of the four major board members; we then assessed the club's relationship with its external stakeholders. The concept of relational resources suggests that stakeholder interactions will be developed by those board members who have the best relationships with specific stakeholders. Although our present research has found no statistical support for the moderating effects of board education and dedication, there is still much work to be done to assess how the management of other board characteristics can affect relations between the sports club and its external stakeholders.

\section{Conclusion}

The main conclusion of this paper is that the management of stakeholders matters in sports organizations. We have provided empirical evidence to show that stakeholder relations are related to the financial and non-financial contributions that non-profit sports organizations are likely to receive from their stakeholders. Managers of sports organizations must cultivate good relations with their external stakeholders to successfully attract more resources from them. We believe that the evidence for this key feature of contemporary management is likely to have an important influence on sports management theory and practice in the coming years.

In line with previous literature on the role of the Board of Directors in the strategic planning of sports organizations, we have assessed the importance of the board in providing resources. Our results show that clubs with dedicated boards willing to make a significant time commitment were more likely to obtain resources from their stakeholders. This raises significant practical implications for the managers of non-profit sports organizations. Since in many instances the Board of Directors is composed not of professional directors, but of volunteer members, it is important to consider how its input into the daily routines and business of the club will translate into higher financial and non-financial resources.

Stressing the importance of time, in contrast with levels of education, has fundamental implications for their management. Given that time dedicated by the Board of Directors has a positive effect on the acquisition of resources, we need to establish specific training activities to help managers maximize the time they invest in the club. The characteristics of voluntary work are well known; we do not intend to replace volunteers with professionals. Our 
objective is to provide volunteers with adequate training, so that they can obtain better resources and strengthen associative activities within the club (Heinemann \& Puig, 1996). Doing this will strengthen civil society and help to win autonomy and authority for its important third sector.

This study involves several limitations that must be considered when generalizing our results. The main limitation is that stakeholder relations were assessed using the perceptions of members of the club's Board of Directors only. Had we asked stakeholders about the quality of their relations with the club, they might have provided very different insights. This highlights a compelling opportunity for future studies, which should shed additional light on this topic by considering the quality of relations from the perspective of other involved parties. Another major area of development will be to analyze those factors that influence the quality of relations with an organization's stakeholder. There is much useful research that can be done into the effective management of sports organization stakeholders. Studies that aim to add knowledge in this area should assess the activities that board members undertake when managing their stakeholders.

To conclude, this paper provides support for the idea that sports clubs must consider the role of their external stakeholders, as well as the needs of their members and other internal stakeholders. Only through additional research will we be able to understand how better to manage the stakeholders of sports organizations.

\section{References}

Agle, B. R., Mitchell, R. K., \& Sonnenfeld, J. A. (1999). Who matters to CEOs? An investigation of stakeholder attributes and saliences, corporate performance, and CEO values. Academy of Management Journal, 42(5), 507-525.

Amis, J., \& Slack, T. (1996). The size-structure relationship in voluntary sports organizations. Journal of Sport Management, 10(1), 76-86.

Berman, S. L., Wicks, A. C., Kotha, S., \& Jones, T. M. (1999). Does stakeholder orientation matter? The relationship between stakeholder management models and firm financial performance. Academy of Management Journal, 42(5), 488-506.

Chelladurai, P. (1987). The design of sport governing bodies: a Parsonian perspective. In T. Slack \& C. R. Hinings (Eds.), The organization and administration of sport (pp. 3757). London, ON: Sports Dynamics.

Donaldson, T., \& Preston, L. E. (1995). The stakeholder theoy of the corporation: concepts, evidence and implications. Academy of Management Review, 20(1), 65-91.

Ferkins, L. (2009). Board involvement in strategy: advancing the governance of sports organizations. Journal of Sport Management, 23(3), 245-277.

Ferkins, L., Shilbury, D., \& McDonald, G. (2005). The role of the board in building strategic capability: towards an integrated model of sport governance research. Sport Management Review, 8(3), 195-225.

Freeman, R. E. (1984). Strategic management: a stakeholder approach. Boston, MA: Pitman.

Freeman, R. E. (1994). The politics of stakeholder theory: Some future directions. Business Ethics Quarterly, 1(4), 409-421.

García-Ferrando, M. (2006). Posmodernidad y Deporte: Entre la individualización y la masificación. Encuesta sobre hábitos deportivos de los españoles 2005. Madrid: Consejo Superior de Deportes, Centro de Investigaciones Sociológicas.

Hambrick, D. C. (2007). Upper echelons theory: an update. Academy of Management Review, 32(2), 334-343.

Hambrick, D. C., \& Mason, P. A. (1984). Upper echelons: the organization as a reflection of its top managers. Academy of Management Review, 9(2), 193-206.

Harrison, J. S., \& Freeman, R. E. (1999). Stakeholders, social responsability and perfomance: Empirical evidence and theoretical perspectives. Academy of Management Journal, 42(5), 479-485. 
Harrison, J. S., \& St. John, C. H. (1996). Managing and partnering with external stakeholders. Academy of Management Executive, 10(2), 46-60.

Heinemann, K. (1999). Sociología del asociacionismo voluntario. El ejemplo del club deportivo. Valencia: Tirant lo Blanch-Asociación Española de Investigación Social aplicada al Deporte.

Heinemann, K. (2005). Sport and the Welfare State in Europe. European Journal of Sport Science, 5(4), 181-188.

Heinemann, K., \& Puig, N. (1996). Sports club management: a comparison. In J. L. Chappelet \& M. H. Roukhadze (Eds.), Sport Management: An International Approach (pp. 93-99). Lausanne: International Olympic Committee.

Heinemann, K., \& Schubert, M. (1994). Der sportverein-ergebnisse einer repräsentativen untersuchung. Schorndorf: Verlag Karl Hofmann.

Horch, H. D. (1996). The German sport club and the Japanese firm: what for-profit organizations can learn from non-profit-organizations. European Journal for Sport Management, 3(1), 21-34.

Hoye, R., \& Cuskelly, G. (2003). Board power and performance within voluntary sport organisations. European Sport Management Quarterly, 3(2), 103-119.

Inglis, S. (1997). Roles of the board in amateur sports organizations. Journal of Sport Management, 11(2), 160-176.

Jones, T. M. (1995). Instrumental stakeholder theory: A synthesis of ethics and economics. Academy of Management Review, 20(2), 404-437.

Krueathep, W., Riccucci, N. \& Suwanmala, C. (2010). Why do agencies work together? The determinants of network formation at the subnational level of Government in Thailand. Journal of Public Administration Research and Theory, 20(1), 157-185.

Leopkey, B., \& Parent, M. M. (2009). Risk management issues in large-scale sporting events: A stakeholder perspective. European Sport Management Quarterly, 9(2), 187-208.

Margolis, J. D., \& Walsh, J. P. (2001). People and profits? The search for a link between a company's social and financial performance. Mahwah, NJ: Lawrence Erlbaum Associates.

Mitchell, R. K., Agle, B. R., \& Wood, D. J. (1997). Toward a theory of stakeholder identification and salience: Defining the principle of who and what really counts. Academy of Management Review, 22(4), 853-886.

Parent, M. M. (2008). Evolution and issue patterns for major-sport-event organizing committees and stakeholders. Journal of Sport Management, 22(2), 135-164.

Parent, M. M., \& Deephouse, D. L. (2007). A case study of stakeholder identification and prioritization by managers. Journal of Business Ethics, 75(1), 1-23.

Puig, N., Martínez, J. \& García, B.(2010). Sport policy in Spain, International Journal of Sport Policy, 2: 3, 381-390.

Secretaria General de l'Esport. Consell Català de l'Esport (2010). Els clubs esportius a Catalunya. Esplugues de Llobregat: Consell Català de l'Esport. Repport written by Marta Pérez and Jordi Viñas.

Sherry, E., \& Shilbury, D. (2009). Board directors and conflict of interest: a study of a sport league. European Sport Management Quarterly, 9(1), 47-62.

Soares, J., Correia, A. \& Rosado, A. (2010). Political factors in the decision-making process in voluntary sports associations. European Sport Management Quarterly, 10(1), 529.

Thiela, A., \& Jochen, M. (2009). Characteristics of voluntary sports clubs management: A sociological perspective. European Sport Management Quarterly, 9(1), 81-98.

Waddock, S. A. \& Graves, S. B. (1997). The corporate social performance-financial performance link. Strategic Management Journal, 18(4), 303-319.

Wood, D. J. (1991). Corporate social performance revisted. Academy of Management Review, 16(4), 691-718. 
Tables and Figues:

Table 1: Justification of stakeholder management

Instrumental Perspective ("We should do it because it will pay off in the end")

- Enhanced ability to predict/control the external environment

- Higher percentage of successful new product/service introductions

- Higher levels of operating efficiency

- Fewer incidents of damaging moves by stakeholders (i.e., boycotts, strikes, bad press)

- Less conflict with stakeholders resulting in fewer legal suits

- More favorable legislation/regulation

- More reasonable contracts

- Higher entry barriers leading to a more favorable competitive environment

- Higher levels of trust

- Greater organizational flexibility

Normative Perspective ("We should do it because it is the right thing to do")

- Moral and philosophical basis for the recognition of stakeholder interests

- Increased media power and heightened interest in corporations

- Statutes that allow board of directors consideration of a broader group of stakeholders

Descriptive Perspective ("We should do it because it will help us to understand our organization and its environment")

- More awareness of the organization's environment

- Better understanding of the consequences of managerial decisions

- More consideration of the organizational environment in the organization's strategy Source: Adapted from Harrison and St. John (1996, p. 48).

Figure 1: Density of the non-financial resources variable

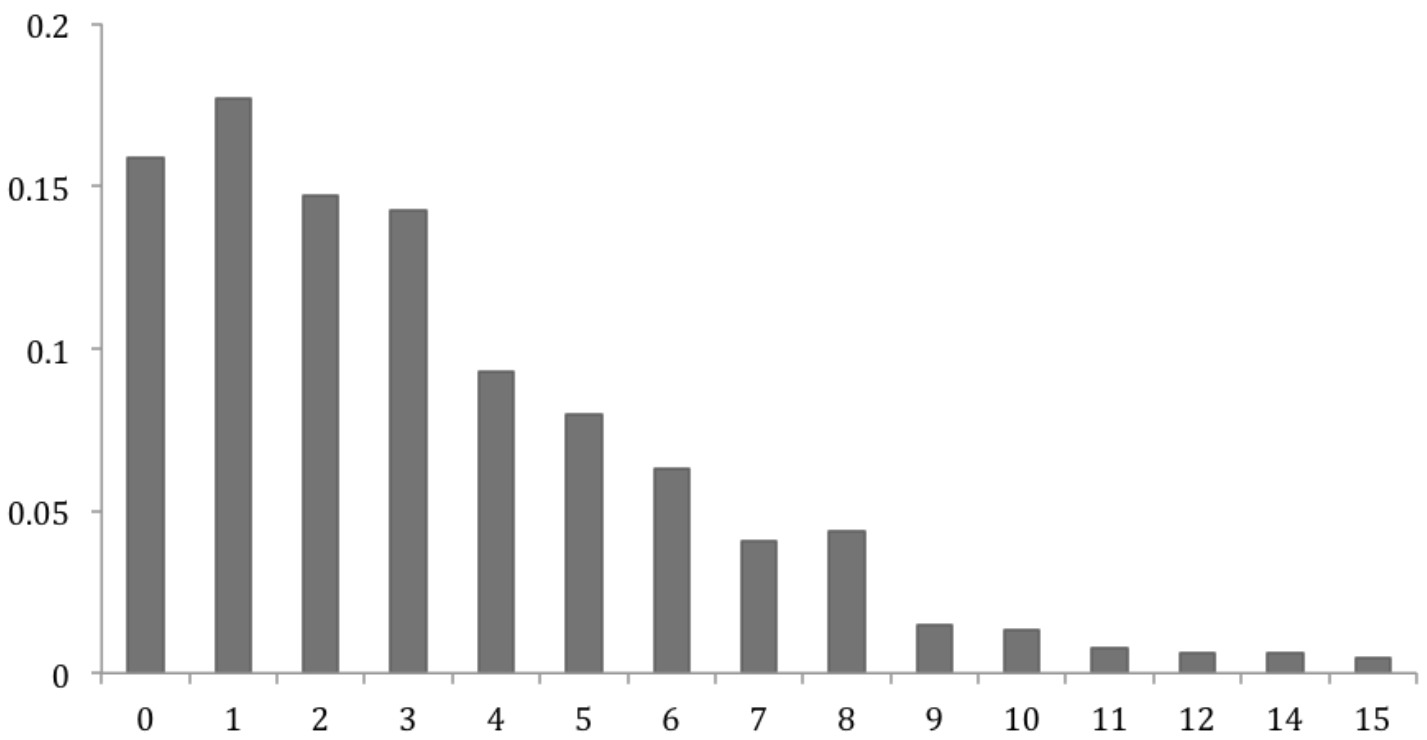




\begin{tabular}{|c|c|c|c|c|c|c|c|c|c|c|c|c|}
\hline Variable & Mean & Std. Dev. & $\mathbf{1}$ & 2 & 3 & 4 & 5 & 6 & 7 & 8 & 9 & $\mathbf{1 0}$ \\
\hline $\begin{array}{l}\text { (1) Collected Financial } \\
\text { Resources (C.F.R.) }\end{array}$ & $2.697,42$ & $4.866,93$ & & & & & & & & & & \\
\hline $\begin{array}{l}\text { (2) Collected Non-Financial } \\
\text { Resources (C.N.F.R.) }\end{array}$ & 3,30 & 2,99 & 0,196 & & & & & & & & & \\
\hline (3) Relationships & 3,86 & 0,87 & 0,055 & 0,180 & & & & & & & & \\
\hline (4) Board Dedication & 1,88 & 0,81 & 0,167 & 0,131 & 0,049 & & & & & & & \\
\hline (5) Board Education & 3,97 & 1,09 & 0,078 & 0,147 & 0,005 & $-0,105$ & & & & & & \\
\hline (6) Size & 4,62 & 1,25 & 0,135 & 0,118 & 0,044 & 0,196 & 0,219 & & & & & \\
\hline (7) Experience & 1,35 & 0,92 & 0,271 & 0,425 & 0,037 & 0,143 & 0,279 & 0,256 & & & & \\
\hline (8) Athletes Quality & 0,13 & 0,34 & 0,082 & 0,149 & 0,017 & $-0,026$ & 0,146 & 0,242 & 0,194 & & & \\
\hline (9) Municipality Size & 10,52 & 2,03 & $-0,019$ & 0,030 & $-0,004$ & 0,126 & 0,207 & 0,144 & 0,171 & 0,182 & & \\
\hline (10) Member Turnover & 5,72 & 12,57 & 0,005 & 0,054 & 0,034 & 0,046 & 0,223 & 0,249 & 0,095 & 0,073 & 0,055 & \\
\hline
\end{tabular}

Note: Coefficients greater than 0.08 in magnitude are significant at $p<0.05$ level 
TABLE 3: Regressions results

\begin{tabular}{|c|c|c|c|c|c|c|c|c|}
\hline \multirow[b]{2}{*}{ Variables } & \multicolumn{4}{|c|}{ COLLECTED FINANCIAL RESOURCES (OLS MODEL) } & \multicolumn{4}{|c|}{ COLLECTED NON-FINANCIAL RESOURCES (NBR MODEL) } \\
\hline & $\begin{array}{l}\text { Model 1: } \\
\text { Controls }\end{array}$ & $\begin{array}{c}\text { Model 2: } \\
\text { Main Effects }\end{array}$ & $\begin{array}{l}\text { Model 3: } \\
\text { Full }\end{array}$ & $\begin{array}{c}\text { Model 4: } \\
\text { Interaction }\end{array}$ & $\begin{array}{l}\text { Model 5: } \\
\text { Controls }\end{array}$ & $\begin{array}{c}\text { Model 6: } \\
\text { Main Effects }\end{array}$ & $\begin{array}{l}\text { Model 7: } \\
\text { Full }\end{array}$ & $\begin{array}{c}\text { Model 8: } \\
\text { Interaction }\end{array}$ \\
\hline Relationships & & $\begin{array}{c}665.650 * * \\
(270.860)\end{array}$ & $\begin{array}{l}602.823^{*} \\
(311.214)\end{array}$ & $\begin{array}{c}1697.65 \\
(1437.628)\end{array}$ & & $\begin{array}{c}.160 * * * \\
(.060)\end{array}$ & $\begin{array}{c}.197 * * * \\
(.052)\end{array}$ & $\begin{array}{l}-.109 \\
(.287)\end{array}$ \\
\hline Board Dedication & & $\begin{array}{c}1425.882 * * * \\
(317.476)\end{array}$ & $\begin{array}{c}1193.505 * * * \\
(354.487)\end{array}$ & $\begin{array}{c}394.2488 \\
(1469.997)\end{array}$ & & $\begin{array}{l}.139 * * \\
(.056)\end{array}$ & $\begin{array}{c}.040 \\
(.059)\end{array}$ & $\begin{array}{l}-.089 \\
(.275)\end{array}$ \\
\hline Board Education & & $\begin{array}{c}548.839 * * \\
(241.477)\end{array}$ & $\begin{array}{c}216.233 \\
(293.485)\end{array}$ & $\begin{array}{l}-1543.619 \\
(1106.227)\end{array}$ & & $\begin{array}{l}.099 * * \\
(.044)\end{array}$ & $\begin{array}{l}.013 \\
(.043)\end{array}$ & $\begin{array}{l}-.212 \\
(.203)\end{array}$ \\
\hline Size & $\begin{array}{c}464.772 * * \\
(222.494)\end{array}$ & & $\begin{array}{c}734.792 * * \\
(306.539)\end{array}$ & $\begin{array}{l}742.252 * * \\
(309.290)\end{array}$ & $\begin{array}{c}.036 \\
(.035)\end{array}$ & & $\begin{array}{c}.002 \\
(.045)\end{array}$ & $\begin{array}{c}.002 \\
(.045)\end{array}$ \\
\hline Experience & $\begin{array}{c}1365.932 * * * \\
(203.417)\end{array}$ & & $\begin{array}{c}1065.257 * * * \\
(309.185)\end{array}$ & $\begin{array}{c}1071.087 * * * \\
(307.754)\end{array}$ & $\begin{array}{c}.432 * * * \\
(.043)\end{array}$ & & $\begin{array}{c}.424 * * * \\
(.052)\end{array}$ & $\begin{array}{c}.421 * * * \\
(.052)\end{array}$ \\
\hline Athletes Quality & $\begin{array}{c}317.386 \\
(665.520)\end{array}$ & & $\begin{array}{c}-42.840 \\
(728.657)\end{array}$ & $\begin{array}{c}-20.167 \\
(724.016)\end{array}$ & $\begin{array}{l}.184^{*} \\
(.107)\end{array}$ & & $\begin{array}{l}.200 * \\
(.120)\end{array}$ & $\begin{array}{l}.209 * \\
(.125)\end{array}$ \\
\hline Municipality Size & $\begin{array}{c}-182.700^{* *} \\
(90.466)\end{array}$ & & $\begin{array}{c}-274.229 * * \\
(135.092)\end{array}$ & $\begin{array}{r}-255.641 * \\
(136.771)\end{array}$ & $\begin{array}{c}-.050 * * * \\
(.019)\end{array}$ & & $\begin{array}{c}-.051 * * \\
(.026)\end{array}$ & $\begin{array}{c}-.049 * * \\
(.025)\end{array}$ \\
\hline Member Turnover & $\begin{array}{l}-12.224 \\
(13.841)\end{array}$ & & $\begin{array}{c}-47.574 * * \\
(19.236)\end{array}$ & $\begin{array}{c}-48.656^{* *} \\
(19.768)\end{array}$ & $\begin{array}{c}.000 \\
(.002)\end{array}$ & & $\begin{array}{l}-.003 \\
(.003)\end{array}$ & $\begin{array}{l}-.003 \\
(.003)\end{array}$ \\
\hline $\begin{array}{l}\text { Interaction } 1 \\
\text { (Relationship x Board } \\
\text { Dedication) }\end{array}$ & & & & $\begin{array}{c}204.263 \\
(387.453)\end{array}$ & & & & $\begin{array}{c}.033 \\
(.069)\end{array}$ \\
\hline $\begin{array}{l}\text { Interaction } 2 \\
\text { (Relationship x Board } \\
\text { Education) }\end{array}$ & & & & $\begin{array}{c}-463.49 \\
(299.7181)\end{array}$ & & & & $\begin{array}{c}.058 \\
(.052)\end{array}$ \\
\hline Constant & $\begin{array}{c}.879 .652 \\
(1239.492)\end{array}$ & $\begin{array}{c}-4136.023 * * * \\
(1553.962)\end{array}$ & $\begin{array}{l}.-3875.328 \\
(2519.721)\end{array}$ & $\begin{array}{c}4674.781 \\
(4943.933)\end{array}$ & $\begin{array}{c}.608 * * * \\
(.072)\end{array}$ & $\begin{array}{l}-.016 \\
(.339)\end{array}$ & $\begin{array}{l}-.255 \\
(.364)\end{array}$ & $\begin{array}{c}1.423 \\
(1.160)\end{array}$ \\
\hline $\mathrm{N}$ & 646 & 487 & 370 & 370 & 454 & 350 & 270 & 270 \\
\hline R-squared & 0,078 & 0,069 & 0,120 & 0,126 & & & & \\
\hline $\mathrm{F}$ & $13.14 * * *$ & $9.82 * * *$ & $7.18 * * *$ & $5.86^{* * *} *$ & & & & \\
\hline Wald Chi2 & & & & & $120.09 * * *$ & $17.40 * * *$ & $90.46^{* * * *}$ & $93.62 * * *$ \\
\hline
\end{tabular}


